https://nv.nltu.edu.ua

https://doi.org/10.15421/40290215

$@ \bowtie$ Correspondence author

Article received 20.03.2019 p.

Article accepted 28.03.2019 p.

A. P. Ivanyuk

удК 630*165.7

\title{
ОСОБЛИВОСТІ РОСТУ БІОГРУПИ ГІРКОКАШТАНА ЗВИЧАЙНОГО У ЗІБОЛКІВСЬКОМУ ЛІСНИЦТВІ ДП "ЖОВКІВСЬКЕ ЛІСОВЕ ГОСПОДАРСТВО"
}

\begin{abstract}
Наведено коротку характеристику гіркокаштана звичайного та досліджено історію створення насадження за участю інтродуцента у Зіболківському лісництві ДП "Жовківське лісове господарство" на початку ХХ ст. Визначено особливості росту досліджуваної породи. Встановлено, що у віці 95 років дерева гіркокаштана звичайного досягають середньої висоти 19,5 м та середнього діаметра 44,3 см. Вивчено процеси природного поновлення інтродуцента та досліджено основні чинники, що впливають на формування підросту. Зроблено порівняльний аналіз природного поновлення гіркокаштана звичайного та клена-явора під наметом деревостану інтродуцента. Встановлено, що самосів гіркокаштана відстає в рості, кількості та життєвості і, перебуваючи в умовах надмірного затінення, "випадає" із підросту до 8-річного віку. Проведені дослідження свідчать, що гіркокаштан звичайний в умовах вологої грабово-соснової судіброви Малого Полісся України досяг найвищого рівня акліматизації - натуралізації, що підтверджує здатність виду до природного поновлення. Розпочаті дослідження мають на меті встановлення перспектив використання породи у лісокультурному виробництві регіону, визначення ступеня натуралізації виду та агресивності його поведінки щодо автохтонних деревних видів рослин у корінних типах лісу.
\end{abstract}

Ключові слова: гіркокаштан звичайний; ріст; формоутворення; природне поновлення; лісові культури.

Вступ. Природний ареал гіркокаштана звичайного (Aesculus hippocastanum L.) розташований у гірських районах Греції, Болгарії, Ірану та північній частині Індіï. Дерево досягає 24-30 м у висоту та 1,5 м у діаметрі (Vorobev, 1982). У лісових насадженнях Західного Лісостепу України, на відміну від зелених насаджень, гіркокаштан звичайний трапляється рідко. Свідченням цього є відсутність згадок про лісові культури цієї породи у працях науковців, що цікавляться інтродукцією листяних порід у регіоні (Tokar, et al., 2016; Kharachko, \& Myklush, 2014).

Отож, виявлення лісового насадження з часткою у складі гіркокаштана звичайного, історія створення якого сягає початку XX ст., $є$ цікавим науковим фактом, який заслуговує, на наш погляд, детального дослідження. Це насадження розміщене у лісовому фонді ДП "Жовківське лісове господарство", а саме у кв. 66 Зіболківського лісництва. У цьому кварталі з порід інтродуцентів також ростуть насадження робінії псевдоакації (Robinia pseudoacacia L.), дуба північного (Quercus borealis Mild.), поодиноко трапляються дерева гледичії трьохколючкової (Gleditschia triacanthos L.). На території лісництва донедавна існувало кілька ділянок лісових культур тополі чорної (Populus nigra L.), які створені в 60-х роках XX ст. 3 хвойних порід-інтродуцентів тут трапляються сосна Веймутова (Pinus strobus L.), сосна жорстка (Pinus rigida L.) і частіше сосна Банкса (Pinus Banksiana Lamb.). Насадження останніх трьох порід теж ростуть у згаданому 66 кварталі та були об'єктами досліджень дисертаційних робіт В. В. Козака (Kozak, 2000), C. В. Жмурка (Zhmurko, 2004) та T. I. Харачка (Kharachko, 2010).

Мета нашої роботи - дослідити історію появи біогрупи гіркокаштана звичайного, вивчити особливості росту породи за лісівничо-таксаційними показниками у деревостанах Зіболківського лісництва та оцінити природне поновлення інтродуцента.

Матеріал і методи дослідження. Під час вивчення лісових культур використовували загальноприйняті методики лісівничо-таксаційних досліджень (Hrom, 2005; Huz, et al., 2011; Shvidenko, et al., 1987; Tsuryk, 2001; Wincenty, Skarbek, 2019; Archiwum Map, 2019; Gadow, 2001). Запас біогрупи гіркокаштана звичайного розраховували за основною таксаційною формулою (діаметр дерева на висоті $1,3 \mathrm{~m}$, його висота та видове число). Вік біогрупи отримали способом підрахунку кількості річних кілець на нульовому зрізі модельного дерева. Тип лісорослинних умов та тип лісу визначали за мето-

\section{Інформація про авторів:}

Харачко Тарас Іванович, канд. с.-г. наук, доцент, кафедра лісових культур і лісової селекції. Email: taras-forester@ukr.net Іванюк Андрій Петрович, канд. с.-г. наук, доцент, кафедра лісових культур і лісової селекції. Email: ivanykandr@ukr.net Король Микола Михайлович, канд. с.-г. наук., доцент, кафедра лісової таксації та лісовпорядкування. Email: nikkorol@ukr.net Мандзюк Роман Іванович, канд. с.-г. наук, наук. співробітник, кафедра лісових культур і лісової селекції. Email: romanmandziuk@gmail.com

Цитування за ДСтУ: Харачко Т. І., Іванюк А. П., Король М. М., Мандзюк Р. І. Особливості росту біогрупи гіркокаштана звичайного у Зіболківському лісництві ДП "Жовківське лісове господарство". Науковий вісник НлтУ України. 2019, т. 29 , № 2. С. 77-81.

Citation APA: Kharachko, T. I., Ivanyuk, A. P., Korol, M. M., \& Mandziuk, R. I. (2019). Features of growth of horse chestnut (Aesculus Hippocastanum L.) biogroup in Zibolkivsky forestry of State Enterprise "Zovkivske forestry". Scientific Bulletin of UNFU, 29(2), 7781. https://doi.org/10.15421/40290215 
дикою типологічних досліджень Д. В. Воробйова (Vorobiov, 1967), Б. Ф. Остапенка (Ostapenko, \& Tkach, 2002). Для визначення видового складу живого надгрунтового вкриття використовували визначник вищих рослин та визначник типів лісорослинних умов М. М. Горшеніна та ін. (Gorshenin, \& Buteiko, 1962). Природне поновлення досліджували за методикою М. М. Горшеніна та ін.

Результати дослідження. Широке розмаїття деревних видів-інтродуцентів у 66 кварталі Зіболківського лісництва тісно пов'язане з розташуванням поблизу, ще за часів правління Австро-Угорщини, а пізніше й за Польщі, садиб лісництва та "гаївки", що розміщувались недалеко одна від одної, біля "Старої дороги", одразу після в'їзду в ліс з боку с. Колоденці Кам'янка-Бузького р-ну Львівської обл. (рис. 1, 2). На сьогодні будівлі не збереглися, але історія про їх існування залишилася в переказах місцевих жителів, а їх тогочасне розташування можна побачити на мапі Військового географічного інституту, виданої в 1936 р. у Варшаві (Archiwum Мар, 2019) (рис. 1). До речі, поряд з цими будівлями існує урочище з назвою "Кватири", що в часи Австро-Угорської імперії слугувало полігоном для літніх військових навчань.

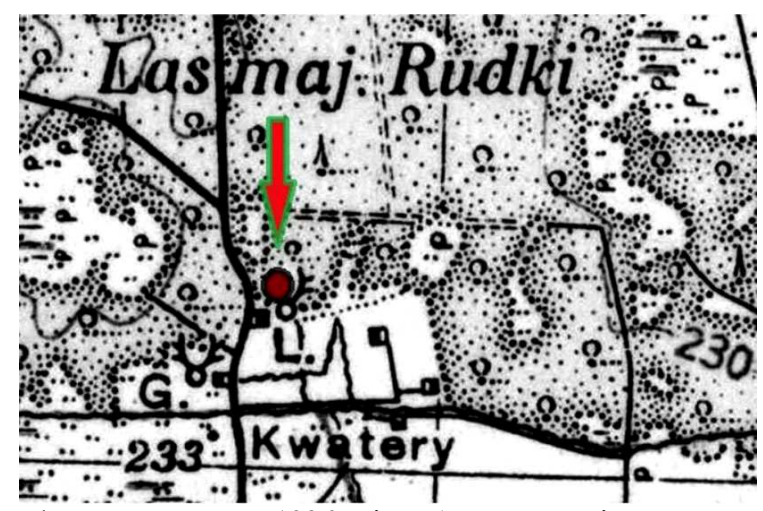

Рис. 1. Фрагмент мапи 1936 р. із зображенням місць розташування будівлі лісництва (позначено латинською літерою "L"), будівлі лісника "гайового" (позначено літерою "G") та розташування біогрупи гіркокаштана звичайного (вказано стрілкою)

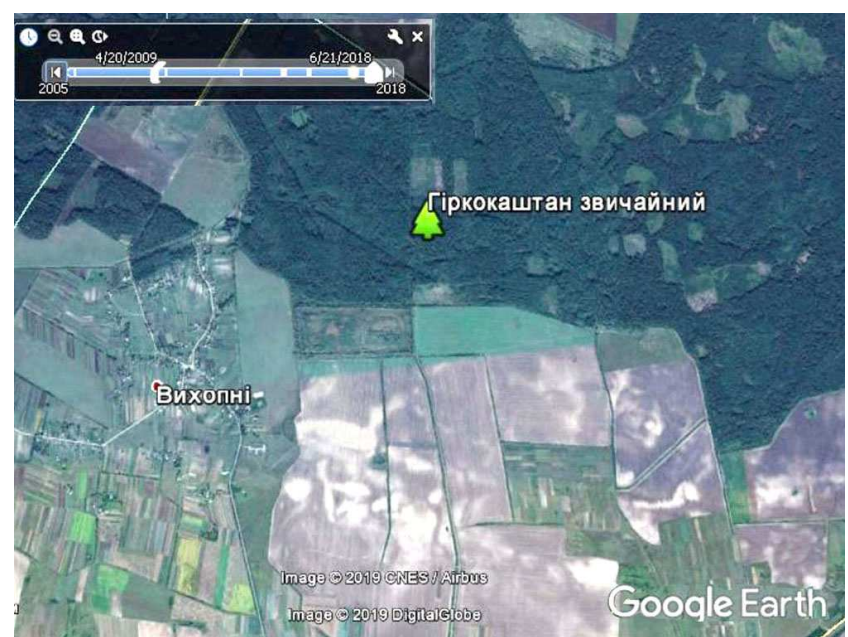

Рис. 2. Розташування біогрупи гіркокаштана звичайного у насадженні Зіболківського лісництва (квартал 66)

Детальніше дослідження історії с. Колоденці свідчить, що у 1909 р. частину його земель разом зі великими площами "Колоденецького лісу" придбав Скарбек Олександр Вінсентій Ян (Wincenty, Skarbek, 2019). О. Скарбек (1874-1922) був видатним польським політиком та громадським діячем тогочасної Галичини.
Час придбання села Олександром Скарбеком майже збігається з віком дерев гіркокаштана звичайного, висаджених навколо лісничівки. Висаджування гіркокаштанів можна пояснити інтенсифікацією роботи лісництва 3 появою нового власника лісу. Різниця у 4 роки між біологічним віком досліджуваних дерев гіркокаштана звичайного та часом придбання села, на нашу думку, пов'язана із висаджуванням на постійне місце 4-річних саджанців.

Створене навколо "лісничівки" насадження заплановане як озеленення садиби, довший час, після знищення будівлі, ймовірно у часі Другої світової війни, зберігало типовий парковий ландшафт із рідко зростаючими деревами з високо піднятими щільними кронами, які, затіняючи собою поверхню грунту, не давали можливості розвитку підліску та підросту аборигенних деревних видів.

Ріст біогрупи гіркокаштана звичайного оцінювали на підставі даних пробної ділянки площею 0,02 га, яку закладено у 2000 р., та аналізу ходу росту за діаметром і висотою модельного дерева віком 95 років. Біогрупа гіркокаштана зростає у вологій грабово-сосновій судіброві $\left(\mathrm{C}_{2}\right.$-гсД), де рельєф ділянки - рівнинний, а тип грунту - дерново-слабопідзолистий супіщаний. Досліджувана біогрупа породи характеризується такими показниками: середня висота - 19,5 м, середній діаметр 44,3 см, кількість дерев - 15 шт., запас на пробній ділянці - $12 \mathrm{~m}^{3}$, запас на 1 га відповідно $600 \mathrm{~m}^{3}$. Підлісок - відсутній, у підрості трапляється клен-явір та гіркокаштан звичайний. Проекційне трав'яне вкриття становить до 10 \% площі, видовий склад - веснівка дволиста (Majanthemum bifolium (L.) F. W.), грястиця збірна (Dactilis glomerata L.), маренка запашна (Asperula graveolens Bied. Ex Sch.), печіночниця звичайна (Hepatica nobilis Mill.).

Ріст дерев гіркокаштана звичайного впродовж віку 95 років аналізували за модельним деревом. Поточний приріст за висотою досліджуваної породи є нерівномірний, тому апроксимацію теоретичних даних проводили на підставі $S$-подібних кривих, а саме Госвальда IV, логістичної та Чапмана-Ріхардса. За методом сум найменших квадратів цю закономірність найкраще описує рівняння Госвальда IV (Pretzsch, 2001). Динаміку росту та приросту цього інтродуцента за висотою наведено на рис. 3, 4. Аналізуючи отримані результати, потрібно зазначити, що приріст гіркокаштана звичайного за висотою у цих умовах є максимальним у віці 40-50 років (до 25 см за рік). Надалі відбувається рівномірний приріст за висотою, а саме у віковому діапазоні від 50 до 80 років, що дорівнює у середньому 21-23 см на рік. Приріст у висоту стрімко зменшується у віці дерева старше 85 років (до 5 см на рік).

Динаміка росту та поточного приросту за діаметром для досліджуваного інтродуцента також добре описується цією S-подібною кривою (Госвальда IV) (рис. 5, 6). Поточний приріст за діаметром, як і за висотою, максимальний у віковому діапазоні 20-30 років (до 1,3 см за рік). Після чого, надалі, відбувається стрімке зниження приросту, й у віці 60 років становить у середньому до 2 мм за рік.

Нерівномірність приросту за діаметром і висотою істотно вплинула на формування твірної стовбура гіркокаштана звичайного. Формування стовбура впродовж його життя та апроксимація форми твірної стовбура достовірно описується функцією Брінка-Гадова (рис. 7, 8). 


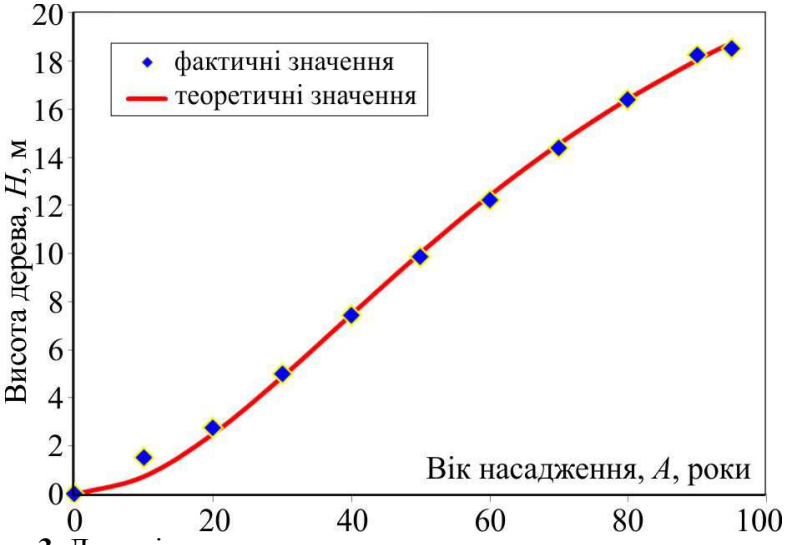

Рис. 3. Динаміка росту за висотою

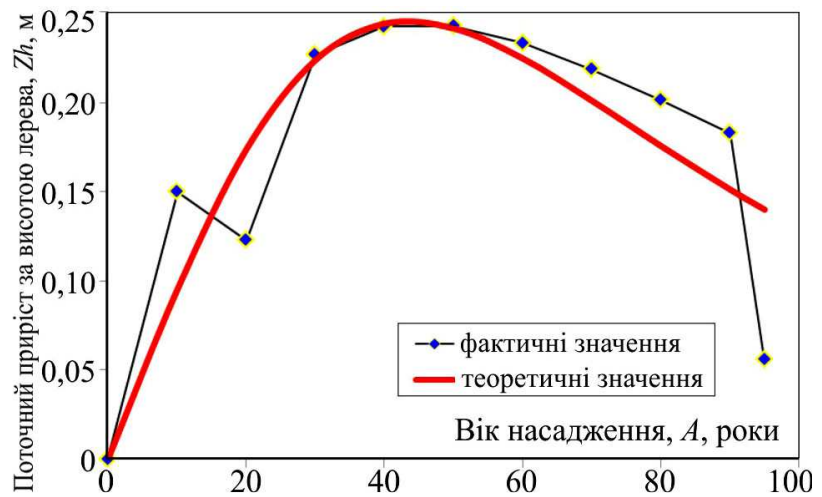

Рис. 4. Динаміка поточного приросту за висотою

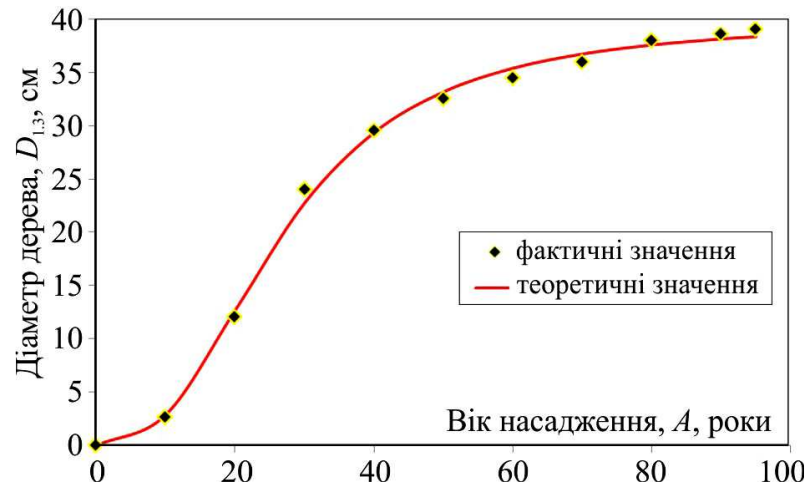

Рис. 5. Динаміка росту за діаметром

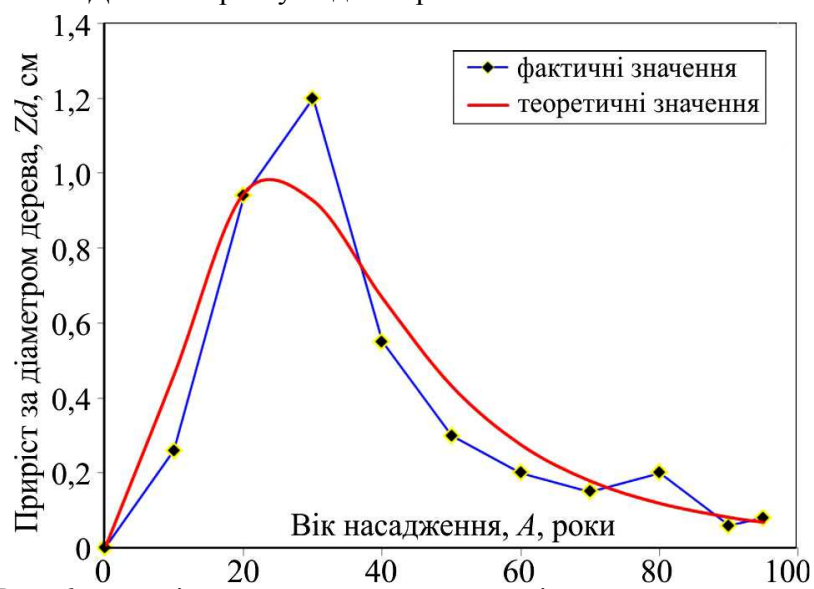

Рис. 6. Динаміка поточного приросту за діаметром

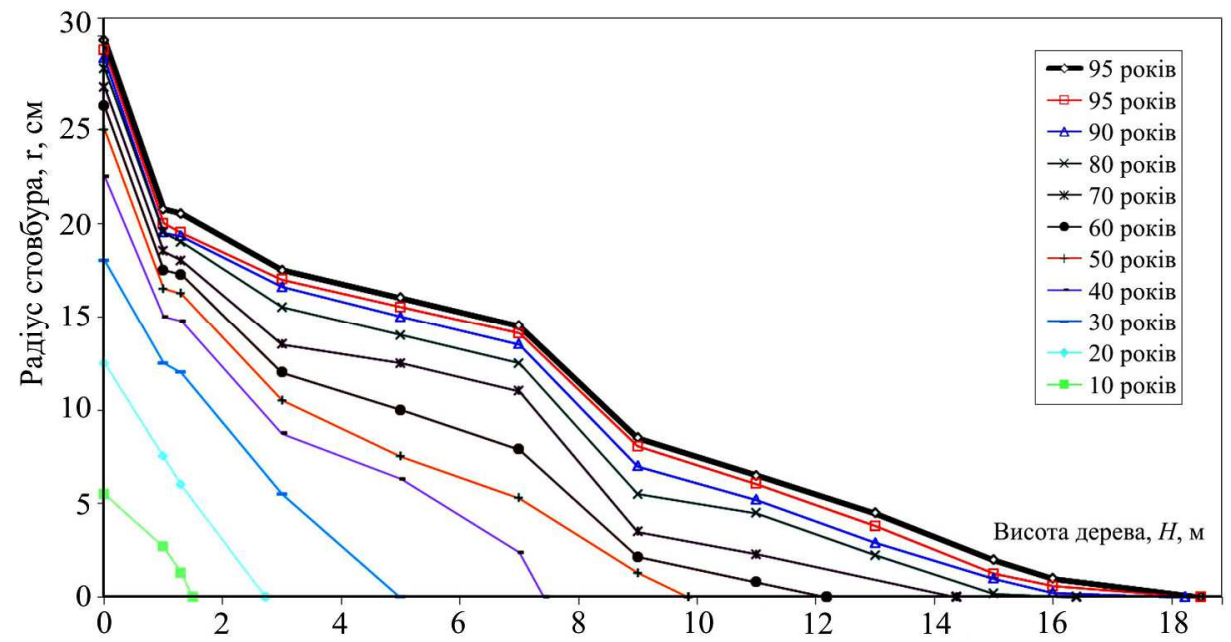

Рис. 7. Фактичне формування твірної стовбура гіркокаштана звичайного

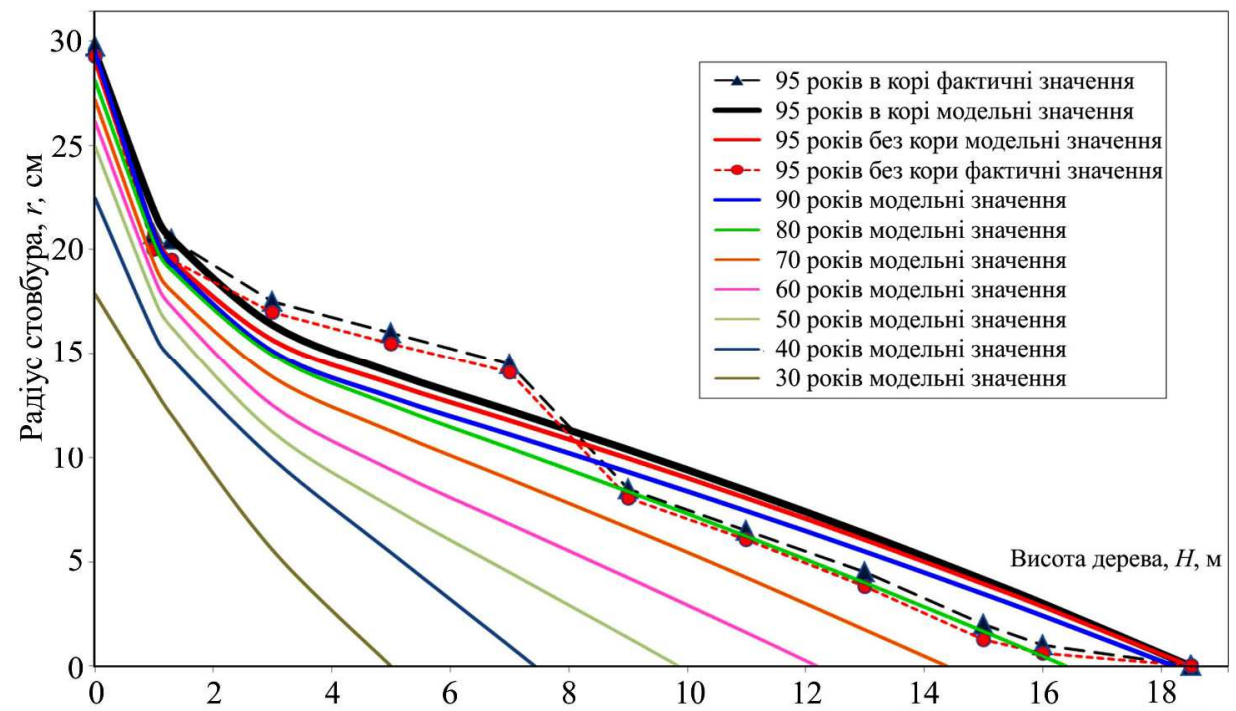

Рис. 8. Теоретичні значення твірної стовбура гіркокаштана звичайного 
До 40 років для гіркокаштана звичайного у цих умовах лінійний приріст за діаметром вздовж стовбура формував спадаючу форму зміни, починаючи із 40-річного періоду формується випуклий тип форми зміни лінійного приросту (рис. 7). Таке формування стовбура впливає на наступний і основний похідний таксаційний показник - об'єм стовбура. Динаміку об'єму та його приросту наведено на рис. 9, 10.

Максимальний поточний приріст гіркокаштана звичайного за об'ємом у цих умовах спостерігається у віці 40 та 80 років, що у середньому становить до 0,012 м³/рік. Середній приріст за об'ємом до віку 70 років зростає і надалі стабілізується, у середньому приростає $0,07-0,08 \mathrm{~m}^{3} /$ рік.

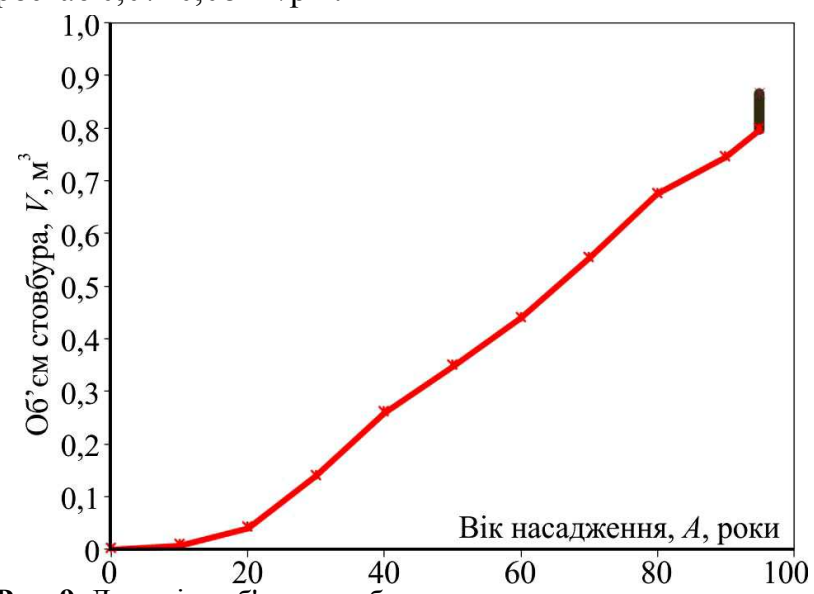

Рис. 9. Динаміка об'єму стовбура

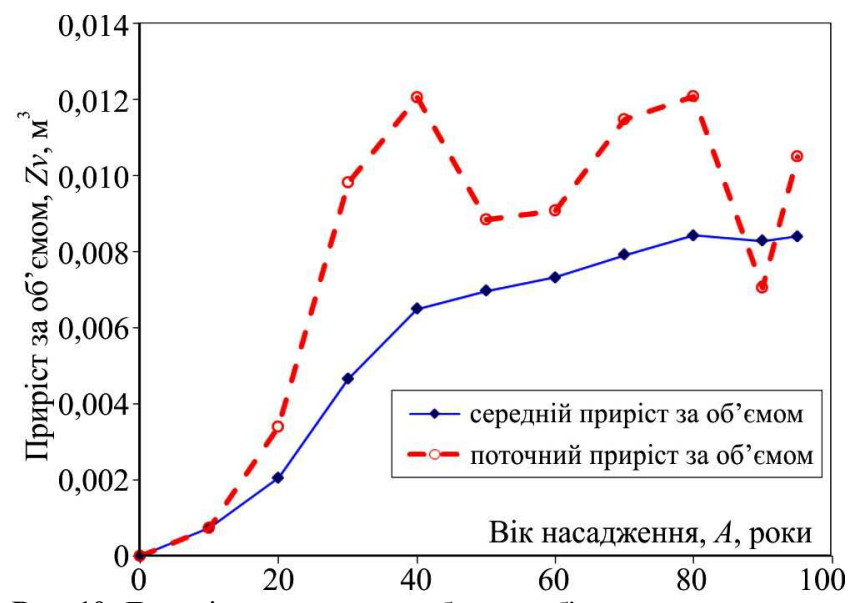

Рис. 10. Динаміка приросту стовбура за об'ємом

Загалом, за результатами дослідження, інтродуцент гіркокаштан звичайний в умовах вологої грабово-соснової судіброви Малого Поліссі України до віку 60 років характеризується задовільним ростом та приростом за основними таксаційними показниками.

Таблиця. Характеристика природного поновлення на пробній ділянці

\begin{tabular}{|c|c|c|c|c|c|c|c|}
\hline \multirow[b]{2}{*}{ Порода } & \multirow[b]{2}{*}{$\begin{array}{l}K^{*}, \\
\text { шт. }\end{array}$} & \multirow{2}{*}{$\begin{array}{l}\text { Трап } \\
\text { лян- } \\
\text { ня, \% }\end{array}$} & \multicolumn{4}{|c|}{\begin{tabular}{|c|} 
Середня кількість підросту за \\
групами віку, тис. шт.га-1 \\
\end{tabular}} & \multirow{2}{*}{$\begin{array}{l}\text { Всього } \\
\text { підрос- } \\
\text { ту, тис. } \\
\text { шт. га-1 }\end{array}$} \\
\hline & & & $\begin{array}{c}1- \\
\text { річки }\end{array}$ & $\begin{array}{c}\text { 2-3- } \\
\text { річки }\end{array}$ & $\begin{array}{l}\text { 4-7- } \\
\text { річки }\end{array}$ & \begin{tabular}{|c|} 
стар- \\
ше \\
7 років
\end{tabular} & \\
\hline Клен-явір & \multirow[b]{2}{*}{10} & 60 & $0,7^{ \pm 0}$ & $12,6^{ \pm 0}$ & $166,1^{ \pm}$ & $0,5^{ \pm 0,05}$ & $180,0^{ \pm 0,0}$ \\
\hline $\begin{array}{l}\text { Гірко- } \\
\text { каштан }\end{array}$ & & 40 & $1,6^{ \pm 0,05}$ & $0,9^{ \pm 0,02}$ & $0,1^{ \pm 0,01}$ & - & $2,6^{ \pm 0,03}$ \\
\hline $\mathrm{Pa}$ & - & - & 2,32 & 13,5 & 166 & 0,54 & 182,6 \\
\hline$\%$ & & & 1,3 & 7,4 & 91,0 & 0,3 & 100 \\
\hline
\end{tabular}

Примітка: $K^{*}$ - кількість облікових площадок.

Природне поновлення оцінювали способом підрахунку кількості підросту за породами на пробній ділян- ці у розрізі вікових груп. Характерним є те, що на дослідній ділянці є два "вікна", які утворилися внаслідок вітровалу дерев минулих років, i, як наслідок, порушилась щільність намету, що спричинило доступ сонячного світла. Це сприяло масовій появі самосіву клена-явоpa, а також гіркокаштана звичайного. Результати обліку природного поновлення на облікових площадках наведено у таблиці.

Порівнюючи природне поновлення гіркокаштана звичайного та клена-явора, а також їх біометричні показники, встановлено, що гіркокаштан відстає в рості, кількості та життєвості, перебуваючи в умовах надмірного затінення. Кількість життєздатного підросту гіркокаштана звичайного, згідно з нормативами інвентаризації та атестацією лісових культур та природного поновлення, є незадовільною, а його розміщення - нерівномірне. Підросту гіркокаштана звичайного старше 7 років не виявлено, що свідчить про слабку конкуренцію відносно аборигенних порід, що потребує додаткового догляду та антропогенного втручання. Значний вплив на зменшення кількості насіння гіркокаштана звичайного та відповідно низьку кількість самосіву, на нашу думку, мають дикі звірі, а саме кабан дикий, оскільки насіння виду $є$ елементом їхньої кормової бази. Водночас, розпушуючи підстилку в пошуках їжі, вони створюють сприятливі умови для появи як самосіву досліджуваного виду, так і автохтонних лісових порід.

3 появою підросту клена-явора біогрупа гіркокаштана втратила свій попередній естетичний "парковий" вигляд i за зовнішнім виглядом трансформувалась у наближене до природи лісове насадження.

Висновки. Аналіз матеріалів наших досліджень дає підстави стверджувати:

- інтродукція гіркокаштана звичайного у лісові насадження Зіболківського лісництва розпочалась на початку XX ст. та пов'язана з придбанням лісу в с. Колоденці політичним та громадським діячем Галичини Олександром Скарбеком;

- гіркокаштан в умовах дослідженого насадження у Малому Поліссі України досяг найвищого рівня акліматизації - натуралізації, що засвідчує здатність виду до природного поновлення;

- природне поновлення інтродуцента значною мірою залежить від розпушування поверхні грунту чи лісової підстилки та трапляється в умовах розріджених насаджень, за умови відсутності процесів задерніння та поїдання насіння кабанами. У зімкнених насадженнях підросту немає;

- гіркокаштан звичайний не $\epsilon$ агресивною породою відносно місцевих деревних видів, а його підріст у вологій грабовососновій судіброві не здатний конкурувати з підростом клена-явора та відмирає до 7-річного віку;

- унікальна 95-річна біогрупа гіркокаштана звичайного у 3іболківському лісництві ДП "Жовківське лісове господарство" $\epsilon$ цінною історичною пам'яткою та природним об'єктом, що потребує збереження та подальшого використання у навчально-просвітницькій і культурно-естетичній cферi.

\section{Перелік використаних джерел}

Archiwum Map. (2019). Archiwum Map Wojskowego Instytutu Geograficznego 1919-1939. Retrieved from: http://polski.mapywig.org/news.php - Title from the screen.

Gadow, K. V. (2001). Waldwachstum. Fakultät für Forstwissenschaften und Waldökologie Georg-August-Universität Göttingen, 212.

Gorshenin, N. M., \& Buteiko, A. I. (1962). Opredelenie tipov uslovii mestoproizrastaniia. Lviv: LGU, 166 p. [In Russian].

Hrom, M. M. (2005). Lisova taksatsiia. Lviv: UkrDLTU, 352 p. [In Ukrainian]. 
Huz, M. M., Horoshko, M. P., Korol, M. M., \& Yaroshchuk, R. A. (2011). Povnoderevnist ta obiemna struktura stovburiv duhlasii (Psevdotsuhy Menzisa) u lisovykh kulturakh Zakhidnoukrainskoi rivnyny. Scientific Bulletin of UNFU, 21(17), 43-49. [In Ukrainian].

Kharachko, T. I. (2010). Yalyna yevropeiska (Picea abies (L.) Karst.) $\mathrm{u}$ lisovykh nasadzhenniakh Maloho Polissia. Abstract of doctoral dissertation for economic Sciences (06.03.01 - Forest Crops and Phytomelioration). Lviv: RVV NLTU Ukrainy, 20 p. [In Ukrainian].

Kharachko, T. I., \& Myklush, S. I. (Ed.). (2014). Istoriia stvorennia nasadzhennia hirkokashtana zvychainoho u Zibolkivskomu lisnytstvi DP "Zhovkivske lisove hospodarstvo". Naukovi osnovy pidvyshchennia produktyvnosti ta biolohichnoi stiikosti lisovykh ta urbanizovanykh ekosystem: Materialy 64-oi naukovo-tekhnichnoi konferentsii profesorsko-vykladatskoho skladu, naukovykh pratsivnykiv, doktorantiv ta aspirantiv za pidsumkamy naukovoi diialnosti u 2013 rotsi. (pp. 130-133). Lviv: RVV NLTU Ukrainy. [In Ukrainian].

Kozak, V. V. (2000). Sosna zhorstka (Pinus rigida Mill.) v lisovykh kulturakh Zakhidnoho i Maloho Polissia. Abstract of Candidate Dissertation for Agricultural Sciences (06.03.01 - Forest Crops, Selection, Farming). Lviv, 18 p. [In Ukrainian].

Ostapenko, B. F., \& Tkach, V. P. (2002). Lisova typolohiia. Kharkiv: KhDAU, 204 p. [In Ukrainian]
Pretzsch, H. (2001). Modellierung des Waldwachstums. Parey Buchverlag Berlin, $341 \mathrm{p}$.

Shvidenko, A. Z., Strochinskii, A. A., Savich, IU. N., \& Kashpor, S. N. (Eds). (1987). Normativno-spravochnye materialy dlia taksatcii lesov Ukrainy i Moldavii. Kyiv: Urozhai, 560 p. [In Russian].

Tokar, O. Ye., Kozel, A. M., Korol, M. M., \& Tsuniak, A. M. (2016). Metody otrymannia parametriv matematychnykh modelei dynamiky derevostaniv. Scientific Bulletin of UNFU, 26(3), 368-373. [In Ukrainian].

Tsuryk, Ye. I. (2001). Taksatsiini pokaznyky y budova nasadzhen. Lviv: UkrDLTU, 360 p. [In Ukrainian].

Vorobev, G. I. (Ed.). (1982). Drevesnye porody mira. (Vol. 2). Filippiny i Iaponiia. Evropa. Sev. Amerika. Avstraliia i Okeaniia. Tcentr. Amerika i strany Karibskogo basseina. (Dolgopolova, V. G. Trans. from English), 76 p. [In Russian].

Vorobiov, D. V. (1967). Metodika lesotipologicheskikh issledovanii. (2nd ed.). Kyiv: Urozhai, 367 p. [In Russian].

Wincenty, A., \& Skarbek, J. (2019). Internetowy polski slownik biograficzny. Retrieved from: http://Aleksander20Wincenty/ 20Jan20Skarbek.mht - Title from the screen.

Zhmurko, S. V. (2004). Sosna Banksa (Pinus banksiana Lamb.) v lisovykh kulturakh Zakhidnoho i Maloho Polissia Ukrainy. Abstract of Candidate Dissertation for Agricultural Sciences (06.03.01 - Forest Crops and Phytomelioration). Lviv, 20 p. [In Ukrainian].

T. I. Kharachko1, A. P. Ivanyuk1, M. M. Korol'1, R. I. Mandziuk ${ }^{2}$

${ }^{I}$ Ukrainian National Forestry University, Lviv, Ukraine

${ }^{2}$ Halych National Nature Park, Halych, Ukraine

\section{FEATURES OF GROWTH OF HORSE CHESTNUT (AESCULUS HIPPOCASTANUM L.) BIOGROUP IN ZIBOLKIVSKY FORESTRY OF STATE ENTERPRISE "ZOVKIVSKE FORESTRY"}

A short description of the horse chestnut is given. It was established that the of introducent's plantation in the Zibolkivsky forestry of the State Enterprise "Zhovkva Forestry" was established at the beginning of the 20th century and is associated with the name of the outstanding public figure of the Galychyna in those times - Oleksandr Skarbek. The productivity indices of planting of the investigated breed are determined. It is established that at the age of 95 years the plantation of the horse chestnut, reaching an average height of $19.5 \mathrm{~m}$ and an average diameter of $44.3 \mathrm{~cm}$, are forming a stock of 1 hectare $-600 \mathrm{~m} 3$. The peculiarities of the natural renewal of the introducent have been studied and the changes in the processes of natural renewal occurrence in the investigated plant have been investigated and the main factors influencing this process are established. A comparative analysis of the natural regeneration of the horse chestnut and sycamore maple (Acer pseudoplatanus L.) under the cover of the introducent tree stand is made. It was established horse chestnut lags behind in growth, quantity and vitality, and, being in conditions of excessive shading, "falls" from the growth to the age of 8 years. The amount of vital undergrowth of the horse chestnut is not satisfactory, and its distribution is uneven. It is established that horse chestnut is not an aggressive breed in relation to local tree species, and its undergrowth is not able to compete with the undergrowth of aboriginal species. The conducted researches show that horse chestnut in the conditions of the wet hornbeam pine sudibrova (mixed oakery) of the Small Polissya of Ukraine has reached the highest level of acclimatization - naturalization, which confirms the ability of the species to a natural renewal. The unique 109-year-old plantation of the horse chestnut in $\mathrm{Zi}$ bolkivsky forestry of the State Enterprise "Zhovkva Forestry" is a valuable historical monument and a natural object requiring a guard regime and its further use as an educational and cultural-aesthetic object. The initiated research is aimed at establishing prospects for the use of breeds in the forest-cultivated production of the region, determining the degree of naturalization of the species and the aggressiveness of its behavior regarding the autochthonous tree species in indigenous forest types.

Keywords: horse chestnut (Aesculus hippocastanum L); growth; formation; natural renewal; forest cultures. 